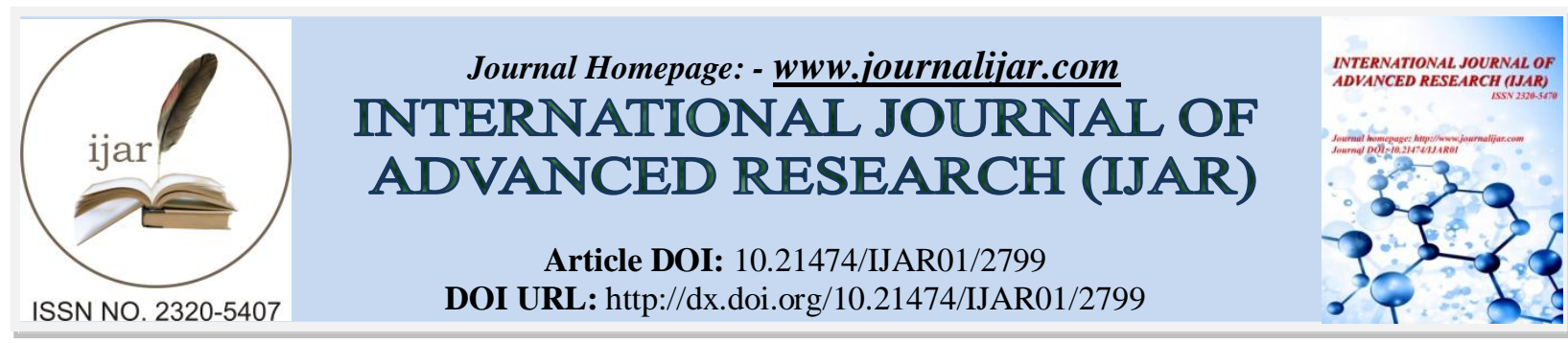

RESEARCH ARTICLE

\title{
ASSESSMENT OF CADMIUM TOXICITY ON THE RED BLOOD CELLS OF AQUATIC LIFE.
}

Alkesh I. Shah

Associate Professor \& Head, Zoology Department, B. P. Baria Science Institute, NAVSARI - 396445, India.

\section{Manuscript Info}

Manuscript History

Received: 15 November 2016

Final Accepted: 17 December 2016

Published: January 2017

Key words:-

Cadmium toxicity, Labeo rohita, Impact on RBC, Heavy metals.

\section{Abstract}

Concentration of aquatic environment with heavy metals has become a matter of great concern because of their toxicity, persistence and bioaccumulation. Cadmium is widely distributed in aquatic environments and is an extremely toxic metal commonly found in industrial settings as a key component in the production of batteries, pigments, coatings and electroplating. Fish play an integral role in the aquatic ecosystem food web and any effects that change the population structure of fish may also alter community and food web dynamics. The consumption of fish is recommended because it is a good source of omega-3 fatty acids, which have been associated with health benefits due to its cardio-protective effects. However, the content of heavy metals such as Cadmium discovered in some makes it difficult to establish clearly the role of fish consumption on a healthy diet. The present study is planned to determine the abnormal morphology of RBC in fish Labeo rohita at different concentration of Cadmium.

Copy Right, IJAR, 2016,. All rights reserved.

\section{Introduction:-}

A Wide range of adverse effects on aquatic organisms have been observed due to heavy metals entering aquatic ecosystem through effluents discharged from industries, mining, fossil fuel combustion, sewage treatment plants and drainage from urban and agricultural areas. Heavy metals are important pollutants because of their environmental persistence and undegradable nature. Cadmium is a well known heavy metal which is extremely toxic. Among heavy metals, Cadmium has been listed in "Blacklist" of European community ${ }^{4}$. It is a non corrosive and highly toxic metal. It is a nonessential element with no known biological function. It is used in batteries, plastics, metal alloys, dye and metal plating industries. Effluents from such activities are sources of Cadmium in aquatic environment. A higher concentration of Cadmium in the aquatic environment is lethal to many organisms, ${ }^{3}$. Cadmium has been considered as an important xenobiotic, persistent and nonbiodegradeable chemical pollutant in the aquatic environment ${ }^{5}$. The adverse causative factors and the sources of contamination of the essential and nonessential heavy metals, such as zinc, copper, cadmium, in aquatic environment are numerous due to increased urbanization, expansion of industrial activity, untreated industrial wasteful effluents, exploration of natural resources, municipal wastes, and the increased use of automobiles ${ }^{2,6,7,8}$.

Cadmium is naturally occurring as well a product of industry and agriculture. Cadmium from fertilizers, manure parent soil and air gets deposited into oceans and seas and is taken up easily by certain seafood. Effluent from electroplating industries manufacturing vinyl plastics, metallurgical operations and mining are the major sources of Cadmium into aquatic environments. Fishes occupy the upper trophic level in aquatic ecosystem and there are 
greater chances of transferring Cadmium to higher organism particularly to human. Cadmium is a recognized carcinogen in mammals. Cadmium has become the focus of global research due to its toxicity to terrestrial and aquatic organisms. The significance of the present study lies in the fact of conservation and protection of aquatic biota which is useful as a food factor for man in long run which needs protection on priority basis.

\section{Methodology:-}

Processing of the fresh water fingerlings major carp Labeo rohita for study:-

Live and healthy fresh water fingerlings major carp Labeo rohita of both sexes were collected from the local fish farms. The fingerlings were transported in polythene bag containing $\mathrm{O}_{2}$ saturated water and brought to the aquarium of the size of $4{ }^{\prime} \times \quad 2$ ' $\quad 2 \quad 2$ nearly 125 to 160 fingerlings of Labeo rohita and were kept as stock. Aquarium containing normal fresh water, commercial fish food was given twice a day. Dissolved Oxygen level and $\mathrm{pH}$ of water was maintained in the laboratory. Experiments were commenced after acclimatizing the fishes to the lab condition for a period ranging from 15 to 20 days. Different concentrations of Cadmium were made by dissolving appropriate amount of analytical grade Cadmium chloride in the fresh water. Live and healthy fresh water fingerlings exposed to different concentration of Cadmium chloride. After exposing to different concentration for different duration 2-3 fingerlings were remove and sacrifice for blood smear study. The thin blood smears were prepared for observing the cellular alterations in the blood cells. The smears were stained with Leishmann's stain and the observations were noted in a tabular form.

\section{Preparation of Cadmium Chloride Samples and Processing of Fingerlings:-}

Different concentration of Cadmium was made by dissolving appropriate amount of analytical grade Cadmium chloride in the fresh water. These sets of different concentration of Cadmium chloride $(5,10,15$ ppm) were prepared for treatment. The fish were divided into different group of 3 individuals each in separate polythene boxes. Commercially available fish food was provided twice a day and water medium with Cadmium chloride was changed every alternate day.

\section{Preparation of Blood Smear:-}

Live and healthy fresh water fish subjected to different concentration of Cadmium chloride (5, 10, 15 ppm). The blood smear was prepared for observation. After an interval of 15 days fish were removed from each container and the blood was drawn from the dorsal aorta or from pressing of gills. A drop of blood was taken on a glass slide and a thin smear was made. It was allowed to dry at room temperature. The slide was then stained with Leishmann's stain for 10 minutes. Then it was washed with distilled water and allowed to dry at room temperature and studied under light microscope. After an interval of 15 days 3 fish were taken from each of the container and made inactive by general hypothermia.

Result of Hematological Studies on Fish Labeo rohita:-

Table:- Effect of Varying Concentrations of Cadmium Chloride on the Normal Blood Cells of Labeo rohita

\begin{tabular}{|c|l|l|l|}
\hline \multirow{2}{*}{$\begin{array}{c}\text { Cadmium } \\
\text { chloride } \\
\text { Concentration }\end{array}$} & \multicolumn{1}{|c|}{$\mathbf{1 5}$ days } & \multicolumn{1}{|c|}{$\mathbf{3 0}$ days } & $\mathbf{4 5}$ days \\
\cline { 2 - 4 } & The cell membrane damaged. & $\begin{array}{l}\text { The cell membrane damaged } \\
\text { and vacullation observed. }\end{array}$ & $\begin{array}{l}\text { The nucleus damaged and } \\
\text { vacullation observed. }\end{array}$ \\
\hline $5 \mathrm{ppm}$ & $\begin{array}{l}\text { The nucleus enlarged and cell } \\
\text { membrane damaged. }\end{array}$ & $\begin{array}{l}\text { The nucleus damaged and the } \\
\text { cell membrane wrinkled. }\end{array}$ & $\begin{array}{l}\text { The nucleus damaged and } \\
\text { the cell membrane wrinkled. }\end{array}$ \\
\hline $10 \mathrm{ppm}$ & The cell membrane wrinkled. & The cell membrane destroyed. & $\begin{array}{l}\text { The cell membrane } \\
\text { destroyed and the } \\
\text { enlarged and damaged. }\end{array}$ \\
\hline
\end{tabular}




\section{Normal Blood Smear of Fish Labeo rohita}

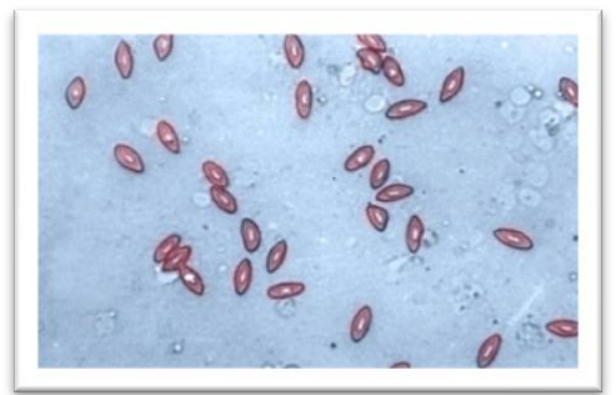

Fish Labeo rohita exhibiting damage to the cell membrane of RBCs

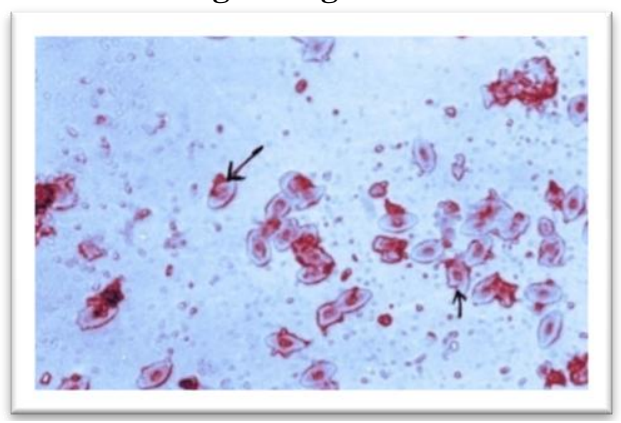

Fish Labeo rohita exhibiting both cell membrane of RBCs damaged with vacillation.

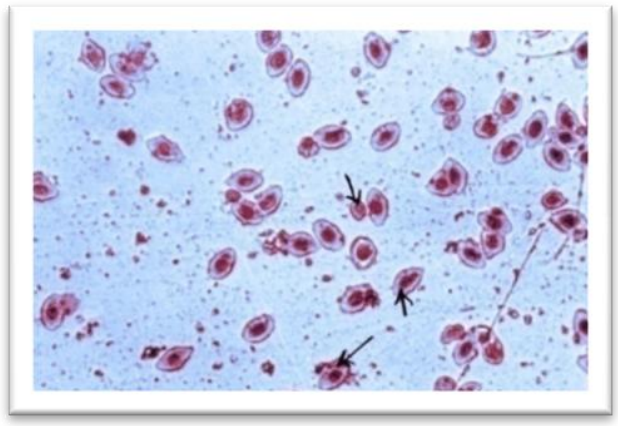

Fish Labeo rohita exhibiting total destruction of the cell membrane of RBCs.

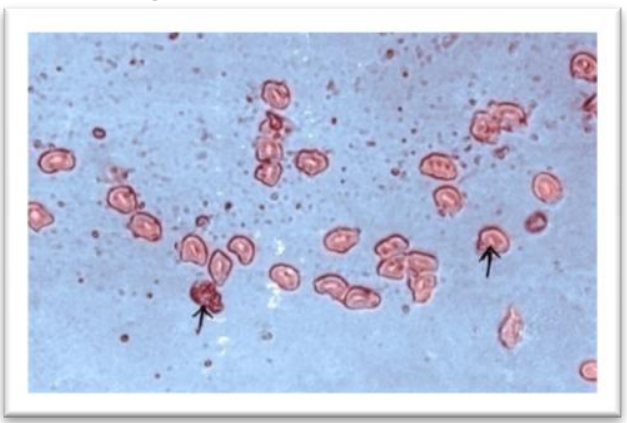


Fish Labeo rohita exhibiting destruction or damage of cell membrane of RBCs with enlargement of nucleus

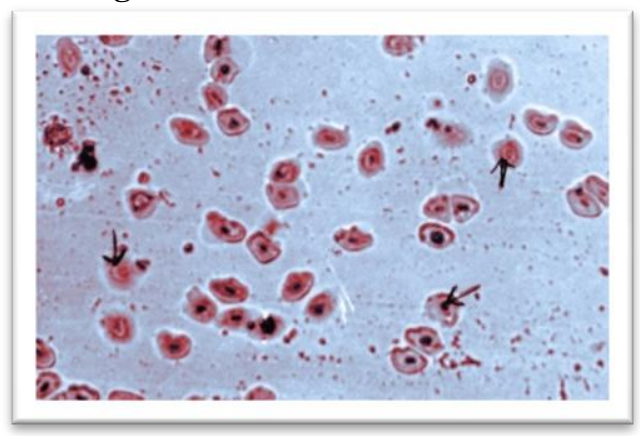

\section{Discussion:-}

During the study of Cadmium Chloride on RBCs 5 ppm concentration exposed to fish on $15^{\text {th }}$ day the cell membrane damaged but in longer duration it was observed on $30^{\text {th }}$ day the cell membrane damaged and vacullation observed. While on $45^{\text {th }}$ day nucleus damaged and vacullation observed. $10 \mathrm{ppm}$ of Cadmium Chloride concentration leads to damage cell membrane and enlarge nucleus even in short term exposure of 15 days. While on $30^{\text {th }}$ and $45^{\text {th }}$ day exposure, there was damaged cell membrane, vacullation and damaged nucleus, accomplished by wrinkled cells. 15 ppm concentration leads to wrinkled cell membrane on $15^{\text {th }}$ day and on $30^{\text {th }}$ day cell membrane was destroyed, while on $45^{\text {th }}$ day cell membrane was damaged or destroyed and nucleus enlarged or damaged ${ }^{1}$.

\section{Conclusion:-}

These types of condition like wrinkled cell membrane, damaged nucleus or enlarged nucleus, vacullation lead either to death of cell in long run or are responsible for anemic condition of animals. Anemic conditions and less iron content have been reported by several workers in fish, bird and mammal following exposure to pollutants. It is also reported that RBCs count was declined by higher concentration of endosulfan subjected to fish. Researchers have postulated that the reduction of RBCs count might be due to inhibition of RBCs production and destruction of RBCs by pollutant. Heavy metals effect on reticulo-endothelial system and haematopoisis.

\section{References:-}

1. Anusha (1994). Effect of endosulfan on oxygen consumption, red blood cell count and food utilization of fresh water fish Clarius dussumieri - I J. Envt. And toxicology: 4(1): 1-63.

2. Ashraj W(2005). Accumulation of heavy metals in kidney and heart tissues of Epinephelus microdon fish from the Arabian Gulf. Environmental Monitoring Assessment; 1-3(103): 311-316.

3. Bhattacharyya, M H., A K Wilson, S S Rajan, and M Jonah (2000). Biochemical pathways in Cadmium toxicity. In Molecular Biology and Toxicology of Metals (RK Zalups and J Koropatnick, Eds.): 34-74, Taylor and Francis, London.

4. Manson, C F(1996). Biology o fresh water pollution. III Edition. Longman, U.K. ; 1-4.

5. McGeer, C J., Cheryl Szebedinszky, D Gordan McDonald, Chris M Wood (2000). Effects of chronic sublethal exposure to water borne Copper, Cadmium and Zinc in Rainbow trout: tissue specific metal accumulation. Aquatic Toxicololgy; 50: 245-256.

6. Saxsena R, Garg P (2011). Vitamin E provides protection against In vitro oxidative stress due to pesticide (Chlorphrifos and Endosulfan) in goat RBC, GERF Bull. Biosci. Article, press.

7. Vinodhini R, Muthuswamy N (2008). Effect of heavy metals induced toxicity on metabolic biomarkers in common carp. Cyprinus carpio. Maejo Int. J. Sci. Technol; 2: 192-200.

8. Vosyliene MZ, Jankaite ZA (2006). Effect of heavy metal model mixture on rainbow trout biological parameters Ekologija, Nr; 4: 12-17.

9. Zyadah, MA, and TE Abde-Baky (2000). Toxicity and bioaccumulation of Copper, Zinc and Cadmium in some aquatic organisms. Bull Environ Contam Toxicol; 64:740-745. 